\title{
A CENTURY IN THE FOREST LIFE OF NEW ZEALAND
}

$\mathrm{O}^{\mathrm{s}}$ E hundred years ago New Zealand had 63 million acres of forest; within eighty years it had been reduced to 12 million. Her woodlands had suffered the fate of those of so many other landsthey had been cut and mangled for immediate gain without any thought of the future. But unlike most lands where this had happened, the New Zealand people awoke to the danger of lost woodlands, and some thirty or forty years ago they decided to change their policy of total destruction for one of preservation and reconstruction. It came gradually, there being a period of overlapping with exploitation and replanting going on side by side. The policy to-day is wholly to preserve and replant.

New Zealand is in the fortunate position that not one part of her forests is inaccessible. The woods are within easy reach of shipping. This contributed in great measure to bring about exploitation, but this same feature will be of inestimable value when she comes to market her timber under a controlled. policy.

For several years now the New Zealanders have led the world in the matter of tree-planting. In seven years alone 400,000 acres were planted. In one year 100,000 acres were planted, which is probably a record for the world. Altogether New Zealand possesses nearly a million acres of young forest.

What helped afforestation most in New Zealand was the discovery of the remarkable growth of certain introduced softwood trees. A pine which came from Monterey, California, namely, Pinus insignis or radiata, was the most remarkable of them all. This tree produces mature timber at 18-30 years of age and pulp wood at 12-14 years of age. The timber of mature trees is equal to the best Baltic pine, and has proved of immense value in making packing cases for dairy produce. It can also be pulped to make paper. One tree which was felled, aged forty-five years, fetched the very high price of $£ 55$.
Other trees which were introduced and reacted satisfactorily to the prevailing conditions were yellow pine, Oregon pine and the redwood of California. Certain poplars also have been making good growth.

The rapidity of growth attracted the attention of the business man. Companies were formed to afforest land and quick returns were obtained from the capital invested. Such a thing is almost unique in the history of forestry, timber growing being usually regarded as a State affair, since it means the locking up of capital for such a long time with very little return.

Within the last year or so the New Zealanders have again shown a great deal of wisdom by turning their attention to the trees which are native to the country. They are preserving what forests remain8 million acres are under State control-and are trying to bring back to them their former grandeur and value.

The most famous natural tree of New Zealand is the kauri pine. Some remnants of it remain. This tree produced some of the best timber the world has ever seen. It also produced the kauri gum, great beds of which still lie in a fossil state in the soil. 15,000 tons of it are mined annually and find a ready market for making paint, varnish and linoleum. The resin from the living tree not only gives gum, but a motor-spirit is also being derived from it now.

There are other native trees such as yellow woods and the Nothofagus, the latter corresponding to the beech of Great Britain. The latter is now being tried on an experimental scale in Britain and is showing great promise. Then there is also the world-famous rimu tree. All these regenerate themselves naturally.

With such success already achieved it is little to be wondered that New Zealand is looking forward to the day when she will be a timber exporting country. E. V. IAAING.

\section{INTERNATIONAL FISHERIES RESEARCH IN THE ATLANTIC*}

\begin{abstract}
$\mathrm{T}$ HE Committee of the Atlantic Continental Slope, on July 16, 1937, formed a sub-committee for the study of a technique concerning researches on the mackerel. Representatives from England, Ireland, France, Portugal and Germany were elected on the sub-committee, which met at the Plymouth Marine Laboratory during December 8-9, 1937. At this meeting discussions took place on: (1) the methods of sampling and selective action of nets; (2) biometrical data; (3) food; (4) age determination; (5) stages of sexual maturity; (6) plankton and hydrographical observations; (7) collection of early metamorphosed stages; (8) commercial statistics ; (9) other researches.

* Rapport Atlantique 1937-1938 (Travaux du Comité du Plateau continental Atlantique) (Atlantic Slope Committee) publié avec l'aide de Ed. le Danois, Dr.Sc. Directeur de l'office des Pêches Maritimes Paris. Rapports et Procès-Verbaux des Réunions, 111, Conseil Permanent international pour l'Exploration de la Mer. Charlottenlund Slot, Danemark. 1939.
\end{abstract}

Reports on the researches on the mackerel by J. le Gall and J. Furnestin (France), G. A. Steven and P. G. Corbin (England) and G. P. Farran (Ireland) show that progress has already been made along these lines. J. le Gall in France has been working on general and seasonal distribution, physicochemical conditions, spawning, food and morphological characters. In Appendix I he gives a résumé of the known facts of the concentration before spawning, spawning periods and sexual maturity, growth and physical conditions of the environment. In Appendix II G. A. Steven and P. G. Corbin report on the work at Plymouth begun in 1936. Both French and English vessels participate in the spring drift fishery, from March until the middle of June, off the western entrance to the English Channel. The fish landed in the early part of the season are often thin, due apparently to absence of food supply. 
When food is available the stomachs are full and later, when zooplankton is plentiful, the mackerel feed voraciously upon this and still later, after the shoals have broken up and dispersed along the shores of the shallow coastal waters, they feed mainly on small fishes.

In 1937 a series of cruises was made in the area to the west of the mouth of the English Channel to try to obtain information concerning the spawning of the mackerel and dispersal and distribution of the young stages. Results from 1938 and 1939 are incorporated in the account. It was found that the spawning is a protracted one lasting from March until July or even August, with its maximum from mid-April to mid-May. It occurs within the area of the Continental shelf, not over great depths, but mainly well off-shore. From April until July there was a gradual eastward shifting of the locality of spawning accompanied by a diminution in the number of eggs. Later on there is found to be a similar eastward drift and decrease in numbers in the young stages. This change in locality with time is foreshadowed by the movements of the shoals which support the commercial drift fishery based on Newlyn from March to mid-June, although routine examination shows that scarcely any ripe or spent mackerel are landed on the fish market before about the end of May. It appears that fishing takes place not on the actual spawning centres but on the inner (landward) edges of them where the fish that have not yet spawned are located. The spawning period of the individuals is found to be a protracted one. The first indication of the spawning condition is the presence of ripe eggs which appear on the outside of the ovary, widely scattered among unripe eggs. Later these ripe eggs pass into the lumen of the ovary, which, externally, then reverts to an unripe appearance. The ripe eggs are shed and the process recurs, possibly many times, before the ovary is fully spent. For study of age and growth-rate it was found that the otoliths carefully prepared are of more value than the scales. Consequently this otolith method has been adopted. Preliminary work shows as yet no dominating year class. Examination of skeletons for racial characters, not yet fully worked out, indicates that the only variant that can be foundthe numbers of the thoracic vertebræ with 'open' hæmal arches-shows some variation from sample to sample.

J. Furnestin in Appendix III shows results chiefly on hydrography and plankton from the entrance to the Channel and waters south of the Irish Sea, and G. P. Farran in Appendix IV deals mainly with the plankton as food for the mackerel.

Besides these researches on the mackerel there are reports by J. le Gall and J. Furnestin on the sardine, plaice, and sand eel, by Fen Hsüeh on Manx herring shoals, by P. Desbrosses on the John Dory and G. P. Farran on surface temperature observations at Coningbeg Lightship on the south coast of Ireland.

\section{AUTOMATIC SERVICE OF LONG-DISTANCE TELEPHONE CALLS}

$\mathrm{F}$ ULL automatic service for toll or long-distance telephone connexions, as they are variously termed, has been in operation in a number of European countries for some years. The administrations and operating companies of countries which have not yet adopted this service are anxiously considering methods of improving their service and reducing its cost. An important paper by W. Hatton, the technical administrator of the Bell Telephone Manufacturing Company at Antwerp, is published in the January issue of Electrical Communication, a quarterly journal issued by the International Standard Electric Corporation of New York, U.S.A.

When converting telephone networks of national dimensions from manual to automatic operation, certain problems arise which can be dealt with in a purely technical manner, while others cannot be solved without due regard to the reaction of the telephone subscriber. Signalling over long-distance circuits by voice-frequency currents, automatic regulation of the transmission level and other technical features of long-distance service do not directly concern the subscriber, provided that the final result is satisfactory. The manner in which charges for long-distance service are established and the form in which the monthly or quarterly account is presented are matters which have both technical and administrative aspects, and in which the subscriber is keenly interested.

To operate long-distance service on an automatic basis, calls must be charged automatically, and the method adopted for this must give complete satis- faction to the subscriber. Prior to the introduction of a system of automatic ticketing, first applied in Belgium, there appeared to be no method of charging subscribers automatically for their long-distance connexions, except by means of the message register. This 'message' method, known to the telephone world as 'time or zone' or sometimes as 'multiple metering', has its disadvantages. A summary of these disadvantages shows that some of them are serious and that business organizations would be reluctant to accept a monthly or quarterly bill without particulars of the individual charges for each of their long-distance connexions. In the case of hotels, these particulars would in most cases need to be furnished immediately on demand. The real solution would have to be one which maintains the present situation between the charges for local and long-distance tariffs (allowing each to be developed to suit their separate requirements) and which at the same time provides a record giving the date, the time of day, the duration of call and the cost of the message, preferably printed on a ticket.

From the practical point of view the design of such a system of automatic ticketing must permit of its introduction to existing exchanges with the minimum of modification to the equipment already installed and in operation. The author gives a sketch of such a system in operation in Belgium which seems to be in every way satisfactory. Although this system is quite a recent invention, there are already installed or on order 150,000 lines.

An excellent description is given by $\mathrm{Mr}$. Hatton of 